\title{
Impact of Environmental Concern on Ecological Purchasing Behavior: The Moderating Effect of Prosociality
}

\author{
Libin Chen ${ }^{1, * \mathbb{D}}$, Qi Wu ${ }^{1}$ and Lin Jiang ${ }^{2}$ \\ 1 Business School, Beijing Technology and Business University, Beijing 100048, China; \\ 2130091071@st.btbu.edu.cn \\ 2 School of Business, Renmin University of China, Beijing 100872, China; 2008000638@ruc.edu.cn \\ * Correspondence: chenlibin@th.btbu.edu.cn
}

Citation: Chen, L.; Wu, Q.; Jiang, L. Impact of Environmental Concern on Ecological Purchasing Behavior: The Moderating Effect of Prosociality. Sustainability 2022, 14, 3004. https:// doi.org/10.3390/su14053004

Academic Editor: Søren Askegaard

Received: 29 January 2022

Accepted: 2 March 2022

Published: 4 March 2022

Publisher's Note: MDPI stays neutral with regard to jurisdictional claims in published maps and institutional affiliations.

Copyright: (C) 2022 by the authors. Licensee MDPI, Basel, Switzerland. This article is an open access article distributed under the terms and conditions of the Creative Commons Attribution (CC BY) license (https:// creativecommons.org/licenses/by/ $4.0 /)$.

\begin{abstract}
Promoting ecological consumption is gradually becoming a social consensus. A crucial point of ecological consumption is consumers' willingness to purchase eco-friendly products, which has become an important consideration for government policymakers. In order to achieve social responsibility, enterprises are also finding ways to encourage consumers to buy eco-friendly products. In this study, we explored the relationship between environmental concern and ecological purchasing behavior, and we tested the moderating effect of prosociality in order to explain why people act in a manner that benefits society. A self-administered questionnaire was developed to gather data, and statistical hypotheses were validated through a structural equation model. The results indicated that enhancing consumers' environmental concerns can effectively influence their eco-purchasing behavior. Therefore, ecological attitude and ecological responsibility have a direct influence on ecological purchasing behavior. Environmental concern positively influences ecological attitude and ecological responsibility through ecological values and ecological affects. Furthermore, the prosociality moderating effect is also significant. Prosociality positively moderates the relationships among ecological responsibility, ecological attitude, and ecological purchasing behavior. The relationships among these factors are important to consider when developing ecological marketing campaigns and communication strategies to influence consumers' ecological behavior. Therefore, fostering prosociality among citizens is also an effective way to enhance the level of eco-consumption.
\end{abstract}

Keywords: environmental concern; ecological values; ecological responsibility; prosociality; ecological purchasing behavior

\section{Introduction}

The pursuit of economic growth and the misuse of natural resources in various countries has caused environmental problems, and many citizens are now becoming concerned about environmental issues, which they believe will affect the welfare and future development of humankind. Concerns about the environment can affect people's behavior in relation to the environment, especially consumers' purchasing behavior. When choosing products, they may give priority to eco-labeled products. Ecological consumerism is emerging, which has influenced practitioners to explore the motives behind consumers' ecological behavior. Most entrepreneurs have already adopted ecological marketing tools, such as ecolabels, eco-brands, and environmental advertising, to emphasize environmentally friendly properties [1]. However, many consumers are wary of buying eco-products because of misleading green advertising [2], the premium price of eco-products [3], or distrust of new technology. Therefore, understanding the mechanisms of consumers' ecological purchasing behavior has considerable implications for ecological marketing.

Previous researchers have discussed the factors influencing ecological purchasing behavior, which can generally be grouped into three categories: personal factors, product marketing factors, and social factors [4]. Personal factors are based on consumers' psychological perceptions, including ecological knowledge [5], ecological emotions [6], ecological 
values [7], and ecological attitudes [8], which can be converted into ecological purchasing intentions/behavior through intrinsic psychological mechanisms. At the level of product marketing factors, ecological concepts such as organic food [9], green electric cars [10], green cosmetics [11], and green furniture products [12] have emerged to attract ecological purchases by consumers. Social factors, such as government regulations, media coverage of environmental protection, or advocacy by environmental organizations, influence the subjective norms of consumers [13].

It is obvious that consumers' ecological purchasing behavior is not only a decision made according to one's personal interests but also one that has a prosocial dimension [14]. This study attempted to explore the mechanisms of environmental concern on eco-purchasing behavior and the influencing relationships among related variables (e.g., ecological values, ecological emotions, ecological attitudes, and ecological responsibility). We also examined the moderating effect of prosociality on ecological purchasing behavior. The remainder of the study proceeds as follows: first, we present the theoretical framework and research hypotheses; second, we introduce the research methodology and analyze the data; and finally, the article discusses the findings and points out the implications and limitations.

\section{Theoretical Background and Hypothesis}

\subsection{Ecological Attitudes and Ecological Purchasing Behavior}

Attitudes are the specific tendencies of individuals to react in a particular context. Ecological attitudes play an important role in addressing environmental issues [15]. They are also related to personal knowledge, values, and worldviews [16]. Schultz et al. called it the sum of beliefs, emotions, and intentions about environmental activities and issues [17]. Furthermore, ecological attitudes are psychological tendencies expressed by evaluating the natural environment favorably or unfavorably to some degree [18].

According to the Theory of Planned Behavior (TPB), consumers' attitudes drive their purchasing behavior [19]. However, the results of empirical studies on the potential association between ecological attitudes and ecological purchasing behavior were mixed [20]. Some studies suggested that attitudes follow behaviors due to cognitive dissonance; individuals need to sustain the behavior that expresses the underlying attitude [21]. As for ecological behavior, it is closely associated with strong ecological attitudes [20]. Many studies perceive environmental attitudes as one of the crucial predictors influencing ecological behavior [14,22,23]. Consumers' attitudes can lead to eco-friendly behavior, which translates into a willingness to pay, thereby having an impact on consumers' subjective norms [24]. Based on the above discussion, we postulate that the more favorable the ecological attitudes of consumers are, the greater the tendency to purchase green products. Hence, the following relationship was hypothesized:

\section{H1. Ecological attitudes positively influence ecological purchasing behavior.}

\subsection{Ecological Responsibility and Ecological Purchasing Behavior}

Under public pressure to protect the environment, aside from corporate social responsibility, consumers need to pay more attention to their role in reducing environmental problems and changing their purchasing behavior responsibly [25]. Consumers' ecological responsibility refers to "the intention of a person to act toward remediation of environmental problems not as an individual user with economic interests but as a responsible citizen having concerns about the social and environmental wellbeing of society" [26]. Stone, Barnes, and Montgomery had earlier specified five elements of ecological responsibility: concern for environmental problems, awareness of environmental problems, possible behaviors, willingness to take action, and ability to solve problems [27]. Pawaskar et al. proposed four elements of ecological responsibility (opinion and beliefs, willingness, awareness, and an ability to act) and treated consumer action as the most important influencing factor [26]. In summary, people must have the ability to take action to minimize damage to 
the environment. Consumers who are ecologically responsible are more eager to promote environmental health [28].

Numerous scholars have explored the relationship between ecological responsibility and ecological purchasing behavior. Bhuian et al. applied the attitude-intention-behavior paradigm to explain that when consumers feel more responsible for the environment, they are motivated to display more environmentally beneficial behaviors, and thus further help themselves achieve success and pleasure [29]. Follows and Jobber, on the other hand, proposed the value-attitude-intention-behavior mechanism to explore ecological purchasing behavior, where the type of value is an important factor in forming different consumer attitudes, as well as an ex-factor that ultimately promotes ecological responsibility and purchasing [30]. Shahrin et al. then verified that environmental responsibility can influence ecological purchasing behavior based on social cognitive theory [31]. Therefore, consumers' ecological responsibility is positively associated with ecological purchasing intentions. The following relationship was therefore hypothesized:

H2. Ecological responsibility positively influences ecological purchasing behavior.

\subsection{Environmental Concern, Ecological Attitudes, and Ecological Responsibility}

Consumers will engage in environmental protection behaviors driven by their intrinsic concern for the environment and society. Environmental concern emerges when people realize that the environment is damaged; in turn, they build their ecological attitude and ecological values [32]. Overall, environmental concern is a cognition formed in the memory through the process of sensory stimulation, attention, recognition, and perception [33]. Scholars have used different scales to measure environmental concern, including the New Environmental Paradigm (NEP) scale [34] and the Ecologically Conscious Consumer Behavior (ECCB) scale [35]. Others have also argued that Ecologically Conscious Consumer Behavior (ECCB) has greater predictive power compared with the New Ecological Paradigm (NEP) scale [36].

Environmental concern has become an essential predictor in the analysis of ecological behavior $[37,38]$. It generally does not directly influence consumer behavior but has indirect effects through factors, such as attitudes [39], subjective norms, and perceived behavioral control [40]. Chen et al. classified environmental concern into three dimensions: egoistic concern, altruistic concern, and biospheric concern, and examined the effects of environmental concern on attitude through Behavioral Reasoning Theory (BRT) [41]. Kirmani and Khan selected collectivism and eco-literacy to predict consumer environmental concern, which helps consumers develop ecological attitudes [42]. Hence, the following relationship was hypothesized:

\section{H3. Environmental concern positively influences ecological attitudes.}

The concept of environmental concern was initially used to explain environmentally responsible behavior [43]. It is often associated with consumers' willingness to purchase eco-labeled products [44]. Considering the urgent need to deal with environmental changes and related issues, a growing number of people have begun to realize their ecological responsibility. Patriotism and ethnocentrism can strongly enhance people's responsibility to take action against environmental problems [45]. Janmaimool and Chudech found that catastrophic domestic and global environmental events can increase students' environmental concern (both domestic and national), thus ultimately enhancing their moral responsibility to protect the environment [46]. Hence, the following relationship was hypothesized:

H4. Environmental concern positively influences ecological responsibility.

\subsection{The Mediating Role of Ecological Values}

Values have different interpretations in different disciplines. In economics, value is an important basis for an economic decision. It acts as a monetary measure of the economic 
benefits received by an individual or group carrying out that activity [15]. In philosophy, values are an individual's trust beliefs, which are viewed as reflecting innate moral beliefs. In social psychology and environmental psychology, values are usually strongly related to environmental concerns. Stern et al. extracted environmental values through VBN theory and explained it in four aspects: altruism, traditional values, self-enhancement, and openness to change [47]. Environmental values are personal values that determine whether to act based on the costs or benefits of a particular behavior with regard to the ecosystem or biosphere [48].

Furthermore, value is vitally important for understanding consumer behavior due to its major role in sustainable consumption [7]. Consumers attach types of values to different products, which, in turn, influence actual purchasing behavior. For example, people will be more likely to choose sustainable products based on their ecological values [49]. Many studies have shown that consumers with high ecological values will contribute more toward ecological marketing outcomes [50]. In the younger generation, increasing environmental education helps them shape ecological values and ecological responsibility [51]. People with stronger self-transcendent values will be more sensitive to environmental issues and more inclined to take ecological responsibility [52]. Hence, the following relationship was hypothesized:

H5. Ecological values mediate the relationship between environmental concern and ecological responsibility.

Attitude is usually defined as an evaluation of a particular target [53]. In social and environmental psychology, the value-attitude-behavior model can be used to explain psychological patterns of consumer behavior [54]. Ecological values significantly motivate positive ecological attitudes [55] and thus promote their purchasing behavior. All three dimensions (biospheric values, altruistic values, and egoistic values) of ecological values are also able to exert significant effects on consumption attitudes [56]. Cheung et al. constructed an extended model of the value-attitude-behavior hierarchy from the perspective of Chinese consumers' ecological purchasing behavior, then tested the positive influence of environmental awareness on values and ecological attitudes [57]. Hence, the following relationship was hypothesized:

H6. Ecological values mediate the relationship between environmental concern and ecological attitudes.

\subsection{Ecological Affects as a Mediator}

When consumers receive ecological marketing information, the mood it evokes needs to be considered, as it can influence their perception. Emotions are related to almost all aspects of consumer behavior [58] and originate from an evaluation of the product that is based on hedonism or utilitarianism [59]. An ecological affect is a factor that generates positive or negative feelings and subsequent emotions, which are stimulated by ecological messages [60].

For consumers, ecological affects are also important in determining their ecological participation and actual purchasing [61]. Kao and Du argued that people's emotions toward environmental behavior are expressed in three main areas: moral emotions, affinity with nature, and ecological fear. Responses to these emotions involve a sense of ecological responsibility and a perception of environmental risk [62]. In the study of ecological responsibility, guilt, as a strong reverse emotion, can guide consumers to display responsible consumption behaviors [63]. Positive emotions, such as pride, can reinforce personal mandates and motivate consumers to responsibly solve sustainable developmental issues [64]. The present study concluded that there is an interactive relationship between consumers' environmental concern, ecological affects, and ecological responsibility. Hence, the following relationship was hypothesized:

H7. Ecological affects mediate the relationship between environmental concern and ecological responsibility. 
Ecological affects and ecological attitudes are important influencing factors in ecological consumption, where ecological affects can significantly influence ecological attitudes [60]. Chan verified the positive effect of ecological affects on ecological attitudes in exploring Chinese consumers' ecological purchasing mechanisms [5]. Ecological affects and environmental concerns also have an impact on ecological purchasing [6]. Matthes, Wonneberger, and Schmuck suggested that consumers with a high level of environmental concern and ecological affects were more likely to show positive attitudes toward ecological brands [65]. Xiao and Dunlap's findings indicated that there is a positive relation between consumers' environmental concerns and ecological attitudes [66]. Hence, the following relationship was hypothesized:

H8. Ecological affects mediate the relationship between environmental concern and ecological attitudes.

\subsection{Prosociality as a Moderator}

People exhibit various forms of prosociality or engage in prosocial behavior. Prosocial behaviors refer to all kinds of actions that benefit others [67]. It has the dual properties of cost and benefit, which are perceived differently from various perspectives [68]. One of the major reasons people engage in prosocial behavior is to reap the reputational benefits associated with being seen as generous [69]. In turn, behavioral costs affect people's psychological perceptions. People are more interested in maintaining a prosocial identity in the future only when the cost is high [70]. Prosociality is defined as "the lasting dispositional tendency for an individual to think about the rights and well-being of others, to feel empathy and worry for others" [71]. It reflects individuals' attitudes toward society and others. Prosocial motivation is developed gradually in infancy by various types of interactions [72]. Children's prosociality can be further enhanced through empathy training [73], prosocial role models [74], praise, and rewards [75]. As people continue to age, their evolving moral competencies allow for greater resilience to social influences [75].

Some scholars have studied prosociality in ecological buying behavior. For example, as noted by Paço, a prosocial attitude is a positive factor in a model of ecological purchasing behavior [71]. Stern et al., on the other hand, directly regarded ecological purchasing behavior as prosocial behavior [47]. Generally speaking, the two items are not the same. Prosocial behavior is a voluntary social behavior based on moral psychology. The peripheral conditions of moral affects, moral judgments, and moral identity can motivate consumers to engage in prosocial behavior [76]. Ecological purchasing behavior, however, is defined as the consumption of environmental, recyclable, and responsible products, which is mostly based on environmental concern [77].

High prosociality is also associated with stronger prosocial personality traits [78]. It can prompt specific behaviors and demonstrate their social properties. Aydinli et al. suggested that high intrinsic prosocial motivation is more likely to drive prosocial behavior [79]. Zabkar and Hosta proposed that highly prosocial identity perceptions can facilitate the translation from environmental concern to purchasing behavior [80]. Ecological responsibility and ecological attitudes are prerequisites for consumers' ecological purchasing willingness. The study assumed that consumers' prosociality can moderate the impact of ecological responsibility and ecological attitudes on ecological purchasing behavior. Hence, the following relationships were hypothesized:

H9. Consumers' prosociality moderates the positive relationship between ecological responsibility and ecological purchasing behavior.

H10. Consumers' prosociality moderates the positive relationship between ecological attitudes and ecological purchasing behavior.

In summary, this study explored the mechanism of environmental concern on consumers' ecological purchasing behavior, which includes five related factors: ecological values, ecological affects, ecological attitudes, ecological responsibility, and prosociality. The theoretical research framework is shown in Figure 1. 


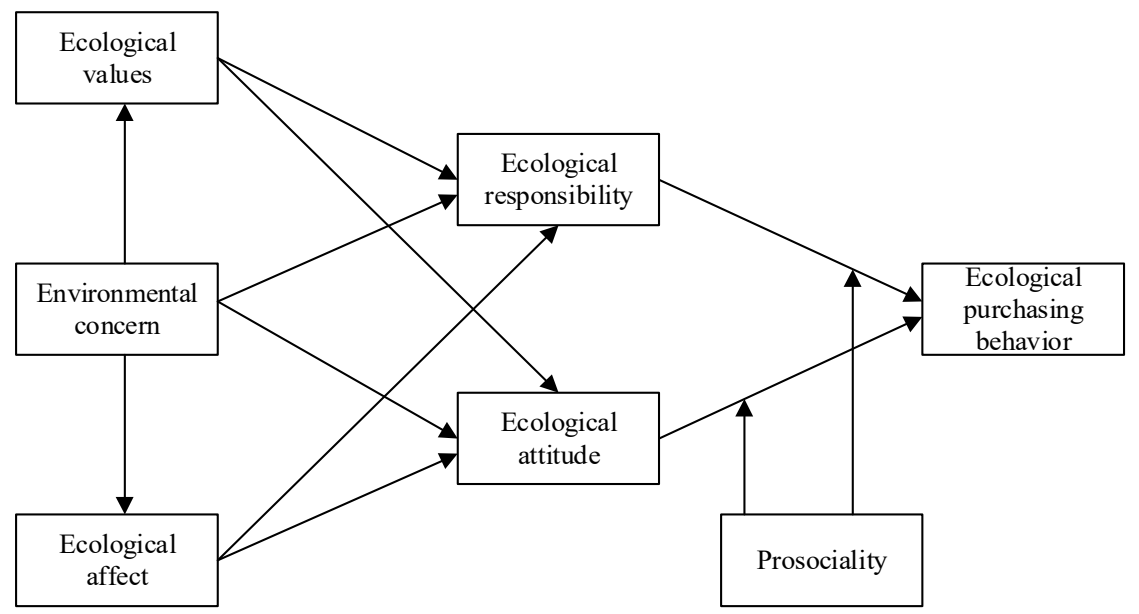

Figure 1. Research model.

\section{Method}

\subsection{Data Collection}

The survey was conducted from July to September 2021. The main respondents were university students and the staff of enterprises and institutions in Beijing, China. The survey was mainly distributed through social media. In total, 523 questionnaires were collected. After removing data with missing or incomplete values, 428 valid responses were subjected to final analysis, with an efficiency rate of $81.8 \%$. As can be seen from Table 1, men accounted for $51.4 \%$ and women accounted for $48.6 \%$, with no significant difference between the two segments. Among the respondents, the 26-30-year-old age group accounted for $42.8 \%$ and the 18-25-year-old age group accounted for $33.9 \%$. Moreover, $76.7 \%$ had a bachelor's degree or above, and $56.3 \%$ were professionals and staff. Regarding income, $59.1 \%$ of the respondents received less than RMB 4000.

\subsection{Measures}

All items were measured on a 7-point Likert scale anchored by " 1 = strongly disagree" and "7 = strongly agree", and items (see Table A1) were translated into Chinese using a standard back-translation procedure. The data were statistically analyzed using AMOS version 26 and SPSS version 26. For hypothesis testing, structural equation modeling (SEM) was used to estimate the direct effects and mediating effects of the theoretical model. A hierarchical regression analysis was conducted to test the moderating effects.

Environmental concern: We used Dunlap, Liere, and Mertig's [34] four-item scale to measure environmental concern. A sample item was "Humans are severely abusing the environment." Cronbach's alpha was 0.89 .

Ecological values: We used Teng, Lu, and Huang's [81] six-item scale to measure ecological values. A sample item was "It makes me sad to see natural environments destroyed." Cronbach's alpha was 0.89 .

Ecological affects: We used Maloney and Ward's [82] scale and refined it into five items before they were used in the comprehensive survey. A sample item was "It frightens me to think that much of the food I eat is contaminated with pesticides." Cronbach's alpha was 0.84 .

Ecological attitudes: We used Chan's [5] three-item scale to measure ecological attitudes. A sample item was "Purchasing ecologically is a good idea". Cronbach's alpha was 0.86 . 
Table 1. Descriptive statistics.

\begin{tabular}{|c|c|c|c|c|}
\hline Characteristic & Category & Frequency & Percentage & Cumulative Percentage \\
\hline \multirow{2}{*}{ Gender } & Male & 220 & 51.4 & 51.4 \\
\hline & Female & 208 & 48.6 & 100.0 \\
\hline \multirow{5}{*}{ Age } & 17 and below & 5 & 1.2 & 1.2 \\
\hline & $18-25$ & 145 & 33.9 & 35.0 \\
\hline & $26-30$ & 183 & 42.8 & 77.8 \\
\hline & $31-40$ & 56 & 13.1 & 90.9 \\
\hline & 41 and above & 39 & 9.1 & 100.0 \\
\hline \multirow{3}{*}{ Education level } & College and below & 100 & 23.4 & 23.4 \\
\hline & Bachelor & 195 & 45.6 & 69.0 \\
\hline & Postgraduate and above & 133 & 31.1 & 100.0 \\
\hline \multirow{6}{*}{ Occupation } & Student & 81 & 18.9 & 18.9 \\
\hline & Staff & 152 & 35.5 & 54.4 \\
\hline & Management & 44 & 10.3 & 64.7 \\
\hline & Teachers & 22 & 5.1 & 69.9 \\
\hline & Professionals & 89 & 20.8 & 90.7 \\
\hline & others & 40 & 9.3 & 100.0 \\
\hline \multirow{5}{*}{ Income } & RMB 2000 and below & 155 & 36.2 & 36.2 \\
\hline & RMB 2001-4000 & 98 & 22.9 & 59.1 \\
\hline & RMB 4001-6000 & 80 & 18.7 & 77.8 \\
\hline & RMB 6001-8000 & 57 & 13.3 & 91.1 \\
\hline & RMB 8001 and above & 38 & 8.9 & 100.0 \\
\hline
\end{tabular}

Ecological responsibility: We used Stern, Powell, and Ardoin's [83] four-item scale to measure ecological responsibility. A sample item was "I can learn how to improve the environment." Cronbach's alpha was 0.85.

Prosociality: We used Paço, Shiel, and Alves's [71] scale and refined it into five items to measure prosociality. A sample item was "It is important to help someone who needs it." Cronbach's alpha was 0.86 .

Ecological purchasing behavior: We used Hoi and Kim's [84] five-item scale to measure ecological purchasing behavior. A sample item was "I have switched products for ecological reasons." Cronbach's alpha was 0.87 .

\section{Results}

\subsection{Confirmatory Factor Analysis}

We used AMOS 26 to conduct a confirmatory factor analysis of environmental concern, ecological affects, ecological responsibility, ecological values, ecological attitudes, prosociality, and ecological purchasing behavior to test the discriminant validity of the variables. As shown in Table 2, the square roots of the average variance extracted (AVE) of all variables in this study were greater than the absolute values of the correlation coefficients between the various latent variables, indicating that the variables had good discriminant validity. 
Table 2. Validity test results.

\begin{tabular}{|c|c|c|c|c|c|c|c|c|c|c|}
\hline Constructs & Std. Estimate & CR & AVE & EV & EC & EAF & EAT & ER & EPB & PSC \\
\hline EV & $0.733-0.784$ & 0.889 & 0.573 & 0.757 & & & & & & \\
\hline EC & $0.751-0.879$ & 0.888 & 0.665 & $0.549 * * *$ & 0.815 & & & & & \\
\hline EAF & $0.671-0.757$ & 0.844 & 0.520 & $0.470 * * *$ & $0.648^{* * *}$ & 0.721 & & & & \\
\hline EAT & $0.793-0.861$ & 0.864 & 0.679 & $0.498^{* * *}$ & $0.491^{* * *}$ & $0.407^{* * *}$ & 0.824 & & & \\
\hline ER & $0.745-0.792$ & 0.852 & 0.591 & $0.500 * * *$ & $0.544^{* * *}$ & $0.587^{* * *}$ & $0.648^{* * *}$ & 0.769 & & \\
\hline $\mathrm{EPB}$ & $0.721-0.796$ & 0.867 & 0.566 & $0.714^{* * *}$ & $0.675 * * *$ & $0.625^{* * *}$ & $0.519^{* * *}$ & $0.533^{* * *}$ & 0.752 & \\
\hline PSC & $0.700-0.773$ & 0.853 & 0.536 & $0.537^{* * *}$ & $0.621^{* * *}$ & $0.759 * * *$ & $0.514^{* * *}$ & $0.612^{* * *}$ & $0.711^{* * *}$ & 0.732 \\
\hline
\end{tabular}

Notes. ${ }^{* * *} p<0.001$. Bold font indicates the square root of the average variance extracted value (AVE) of the variables. Std. Estimate indicates the interval of the standardized coefficients for each question term of the variables. EC, environmental concern; EV, ecological values; EAF, ecological affects; EAT, ecological attitudes; ER, ecological responsibility; PSC, prosociality; EPB, ecological purchasing behavior.

\subsection{Common Method Bias Testing}

Since the questionnaire items were completed by the same participant in the form of a self-report, the problem of homogeneous error may exist. As shown in Table 3, there was no high correlation between the latent variables $(r>0.90)$, tentatively demonstrating that the sample data were less affected by common method bias. By applying Harman's one-factor test, all measures were subjected to unrotated factor analysis using SPSS 26, which extracted six common factors. The largest factor explained $38.784 \%$ of the total variance, which was less than $40 \%$, indicating that the data in this study were less affected by homogeneous error problems.

Table 3. Descriptive statistics of the variables.

\begin{tabular}{ccccccccc}
\hline Constructs & $\mathbf{M}$ & SD & EV & EC & EAF & EAT & ER & EPB \\
\hline EV & 5.254 & 0.909 & 1 & & & & & \\
EC & 5.062 & 1.098 & $0.496^{* *}$ & 1 & & & & \\
EAF & 5.109 & 0.994 & $0.403^{* *}$ & $0.567^{* *}$ & 1 & & & \\
EAT & 5.281 & 1.055 & $0.438^{* *}$ & $0.432^{* *}$ & $0.346^{* *}$ & 1 & & \\
ER & 5.339 & 0.903 & $0.442^{* *}$ & $0.479^{* *}$ & $0.502^{* *}$ & $0.555^{* *}$ & 1 & 1 \\
EPB & 5.089 & 0.920 & $0.625^{* *}$ & $0.602^{* *}$ & $0.540^{* *}$ & $0.447^{* *}$ & $0.462^{* *}$ & 1 \\
PSC & 5.063 & 0.875 & $0.444^{* *}$ & $0.516^{* *}$ & $0.631^{* *}$ & $0.430^{* *}$ & $0.507^{* *}$ & $0.581^{* *}$ \\
\hline
\end{tabular}

Notes. ${ }^{* *} p<0.01$. EC, environmental concern; EV, ecological values; EAF, ecological affects; EAT, ecological attitudes; ER, ecological responsibility; PSC, prosociality; EPB, ecological purchasing behavior.

\subsection{Descriptive Statistics}

Table 3 lists the means, standard deviations, and Pearson correlation coefficients of all latent variables. These variables' data show moderate positive correlations with each other. Ecological values and ecological attitudes positively correlated with environmental concern $(r=0.496 ; r=0.432)$. Ecological affects and ecological responsibility positively correlated with environmental concern $(r=0.567 ; r=0.479)$. In addition, ecological responsibility and ecological attitudes both positively correlated with ecological purchasing behavior $(r=0.462 ; r=0.447)$.

\subsection{Model Fit and Hypothesis Testing}

Prior to hypothesis testing, we conducted analyses to determine the acceptability of the measurement models. The root mean square error of approximation (RMSEA), the incremental fit index (IFI), the comparative fit index (CFI), and the Tucker-Lewis index (TLI) were analyzed with Analysis of Moment Structure (AMOS) software to assess the model fit. The results indicated (see Table 4 ) that the measurement model is within the acceptable range. The measurement model's fit values are as follows: $\chi^{2}=791.003, \mathrm{df}=443$, $\chi^{2} / \mathrm{df}=1.786, \mathrm{IFI}=0.955, \mathrm{CFI}=0.955, \mathrm{TLI}=0.949$, and RMSEA $=0.043$. The structural model fit values $\left(\chi^{2}=815.438, \mathrm{df}=314, \chi^{2} / \mathrm{df}=2.597, \mathrm{IFI}=0.923, \mathrm{CFI}=0.922, \mathrm{TLI}=0.913\right.$, and RMSEA $=0.061$ ) were also satisfactory. 
Table 4. Fit coefficient analysis.

\begin{tabular}{ccccccccc}
\hline Model & $\boldsymbol{x}^{2}$ & DF & $\boldsymbol{P}$ & $\boldsymbol{\chi}^{2} / \mathrm{DF}$ & RMSEA & IFI & CFI & TLI \\
\hline $\begin{array}{c}\text { Measurement model } \\
\text { (seven factors) } \\
\begin{array}{c}\text { Structural model } \\
\text { (six factors) }\end{array}\end{array}$ & 791.003 & 443 & $* * *$ & 1.786 & 0.043 & 0.955 & 0.955 & 0.949 \\
\hline
\end{tabular}

Note: ${ }^{* * *} p<0.001$. The seven factors include environmental concern, ecological values, ecological affects, ecological responsibility, ecological attitudes, prosociality, and ecological purchasing behavior; the six factors include environmental concern, ecological values, ecological affect, ecological responsibility, ecological attitudes, and ecological purchasing behavior.

Based on the fitting coefficients above, further hypothesis testing using SEM was adopted in this study, and the maximum likelihood method was used for parameter estimation. $\mathrm{H} 1$ and $\mathrm{H} 2$ predict the simple relationships among ecological attitudes, ecological responsibility, and ecological purchasing behavior; $\mathrm{H} 3$ and $\mathrm{H} 4$ predict the relationships among ecological attitudes, environmental concern, and ecological responsibility. The results of hypothesis testing are shown in Table 5. Ecological attitudes and ecological responsibility were both positively related to ecological purchasing behavior; environmental concern positively influenced ecological attitudes, while environmental concern did not have an impact on ecological responsibility. In summary, H1 to H3 were all supported, but H4 failed.

Table 5. Hypothesis testing results.

\begin{tabular}{|c|c|c|c|c|c|}
\hline Paths & Std. Estimate & Estimate & S.E. & C.R. & $p$ Value \\
\hline Environmental concern $\rightarrow$ Ecological responsibility & 0.185 & 0.160 & 0.064 & 2.516 & 0.093 \\
\hline Environmental concern $\rightarrow$ Ecological attitude & 0.247 & 0.256 & 0.081 & 3.15 & * \\
\hline Ecological responsibility $\rightarrow$ Ecological purchasing behavior & 0.422 & 0.436 & 0.062 & 7.039 & $* * *$ \\
\hline Ecological attitude $\rightarrow$ Ecological purchasing behavior & 0.325 & 0.280 & 0.049 & 5.763 & $* * *$ \\
\hline
\end{tabular}

Note: ${ }^{* * *} p<0.001,{ }^{*} p<0.05$.

\subsection{Mediating Effect Analyses}

This study used Hayes and Preacher's [85] method to test mediation by the bootstrapping test with 5000 repeated samples and by constructing $95 \%$ bias-corrected confidence intervals. The results for mediating effect are shown in Table 6. All indirect effect tests were significant, except for the mediating role of ecological affects between ecological attitudes and environmental concern, as its confidence interval contained 0 . The direct and indirect effects are summarized as follows. The mediating effects of ecological values and ecological affects between environmental concern and ecological responsibility were $0.138(27 \%)$ and $0.218(42 \%)$, respectively, while the confidence interval of the direct effects of environmental concern and ecological responsibility $(\mathrm{LLCI}=-0.027, \mathrm{ULCI}=0.356)$ contained 0 . Thus, ecological values and ecological affects play a fully mediating role in the relationship between environmental concern and ecological responsibility. $\mathrm{H} 5$ and $\mathrm{H} 6$ were verified. The indirect effect of ecological responsibility between environmental concern and ecological attitude was $0.197(36 \%)$, while the confidence interval of the direct effect of environmental concern and ecological attitude (LLCI $=0.108$, ULCI $=0.326)$ did not contain 0 . Therefore, we can claim that ecological values play a partially mediating role between environmental concern and ecological attitudes. H7 was supported. The lack of significance in the indirect effects of ecological affects between environmental concern and ecological attitudes suggests that ecological affects have no mediating role in the process. H8 cannot be supported. 
Table 6. Mediation results.

\begin{tabular}{|c|c|c|c|c|c|c|c|c|}
\hline \multirow{2}{*}{ Paths } & \multirow{2}{*}{ Estimate } & \multirow{2}{*}{$\begin{array}{c}\text { Value } \\
\text { Percentage (\%) }\end{array}$} & \multicolumn{2}{|c|}{ Products of Coefficients } & \multicolumn{3}{|c|}{ Bias-Corrected $95 \% \mathrm{CI}$} & \multirow{2}{*}{ Mediation } \\
\hline & & & SE & $\mathbf{Z}$ & Lower & Upper & $P$ & \\
\hline \multicolumn{9}{|c|}{ Indirect effects } \\
\hline $1 \mathrm{EC} \rightarrow \mathrm{EV} \rightarrow \mathrm{ER}$ & 0.138 & 26.796 & 0.044 & 3.136 & 0.059 & 0.232 & 0.001 & Full \\
\hline $2 \mathrm{EC} \rightarrow \mathrm{EAF} \rightarrow \mathrm{ER}$ & 0.218 & 42.330 & 0.063 & 3.460 & 0.110 & 0.356 & $* * *$ & Full \\
\hline $3 \mathrm{EC} \rightarrow \mathrm{EV} \rightarrow \mathrm{EAT}$ & 0.197 & 36.213 & 0.055 & 3.582 & 0.108 & 0.326 & $* * *$ & Partial \\
\hline $4 \mathrm{EC} \rightarrow \mathrm{EAF} \rightarrow \mathrm{EAT}$ & 0.091 & 16.728 & 0.076 & 1.197 & -0.050 & 0.248 & 0.199 & None \\
\hline \multicolumn{9}{|c|}{ Direct effects } \\
\hline $\mathrm{EC} \rightarrow \mathrm{ER}$ & 0.160 & 31.068 & 0.098 & 1.633 & -0.027 & 0.356 & 0.091 & \multirow{2}{*}{--} \\
\hline $\mathrm{EC} \rightarrow \mathrm{EAT}$ & 0.256 & 47.059 & 0.121 & 2.116 & 0.015 & 0.491 & 0.039 & \\
\hline \multicolumn{9}{|c|}{ Contrasts } \\
\hline Dif 1 vs. 2 & -0.081 & \multirow{2}{*}{--} & 0.067 & -1.209 & -0.234 & 0.049 & 0.215 & \multirow{2}{*}{--} \\
\hline Dif 3 vs. 4 & 0.120 & & 0.088 & 1.364 & -0.087 & 0.292 & 0.252 & \\
\hline
\end{tabular}

Note. ${ }^{* * *} p<0.001$. EC, environmental concern; EV, ecological values; EAF, ecological affects; EAT, ecological attitudes; ER, ecological responsibility.

\subsection{Moderating Effect Analyses}

In the study, the hierarchical regression method of Baron-Kenny was used to examine the moderating effects of prosociality on the relationships among ecological attitudes, ecological responsibility, and ecological purchasing behavior (Table 7). Following the suggestions of Aiken and West [86], the variables were centered and their interaction was calculated, which made the coefficients of the regression equation more explanatory. The regression equation for testing this moderating effect has the following two interactions:

$$
\begin{gathered}
y=a+b x+c m+e \\
y=a+b x+c m+k x m+e
\end{gathered}
$$

\begin{tabular}{|c|c|c|c|c|}
\hline \multirow{2}{*}{ Variables } & \multicolumn{2}{|c|}{ EPB } & \multicolumn{2}{|c|}{ EPB } \\
\hline & Equation (1) & Equation (2) & Equation (1) & Equation (2) \\
\hline \multicolumn{5}{|c|}{ Independent variable } \\
\hline ER & $0.225^{* * *}$ & $0.249^{* * *}$ & & \\
\hline EAT & & & $0.242^{* * *}$ & $0.269 * * *$ \\
\hline \multicolumn{5}{|c|}{ Moderating variable } \\
\hline PSC & $0.467^{* * *}$ & $0.506^{* * *}$ & $0.477^{* * *}$ & $0.531^{* * *}$ \\
\hline \multicolumn{5}{|l|}{ Interaction } \\
\hline ER*PSC & & 0.097 * & & \\
\hline $\mathrm{EAT}^{* P S C}$ & & & & $0.138^{* *}$ \\
\hline $\mathrm{R}^{2}$ & 0.376 & 0.382 & 0.386 & 0.400 \\
\hline$\left(\right.$ Adjusted $R^{2}$ ) & $(0.373)$ & $(0.378)$ & $(0.383)$ & $(0.395)$ \\
\hline F & 127.801 & 87.386 & 133.418 & 94.122 \\
\hline (Sig.) & (0.000) & (0.000) & (0.000) & (0.000) \\
\hline
\end{tabular}

Table 7. The results for moderating effects.

Note: ${ }^{* * *} p<0.001,{ }^{* *} p<0.01,{ }^{*} p<0.05$. EC, environmental concern; EV, ecological values; EAF, ecological affects EAT, ecological attitudes; ER, ecological responsibility; PSC, prosociality; EPB, ecological purchasing behavior.

In Equations (1) and (2), ' $x$ ' represents the independent variable, ' $m$ ' represents the moderating variable, ' $\mathrm{xm}$ ' represents the moderating effect of the interaction term, and ' $\mathrm{k}$ ' is the presence or absence of a statistically significant critical ratio (at the 0.05 level) to represent the moderating effect. 
At first, the moderating effect of prosociality between ecological responsibility and ecological purchasing behavior was assessed. As can be seen in Table 7, after adding the interaction term of ecological responsibility and prosociality in Equation (2), the regression coefficient of the interaction term was significant $(p<0.050)$. This indicates that the moderating role of prosociality between ecological responsibility and ecological purchasing behavior was positive. H9 was supported. To test H9 more intuitively, a simple slope test was conducted using the method proposed by Dawson [87] and Dawson and Richter [88]. As can be seen from Figure 2, the regression line of ecological purchasing behavior is steeper under high prosociality compared with under low prosociality. It can be concluded that the positive effect of ecological responsibility on ecological purchasing behavior is greater under high prosociality.

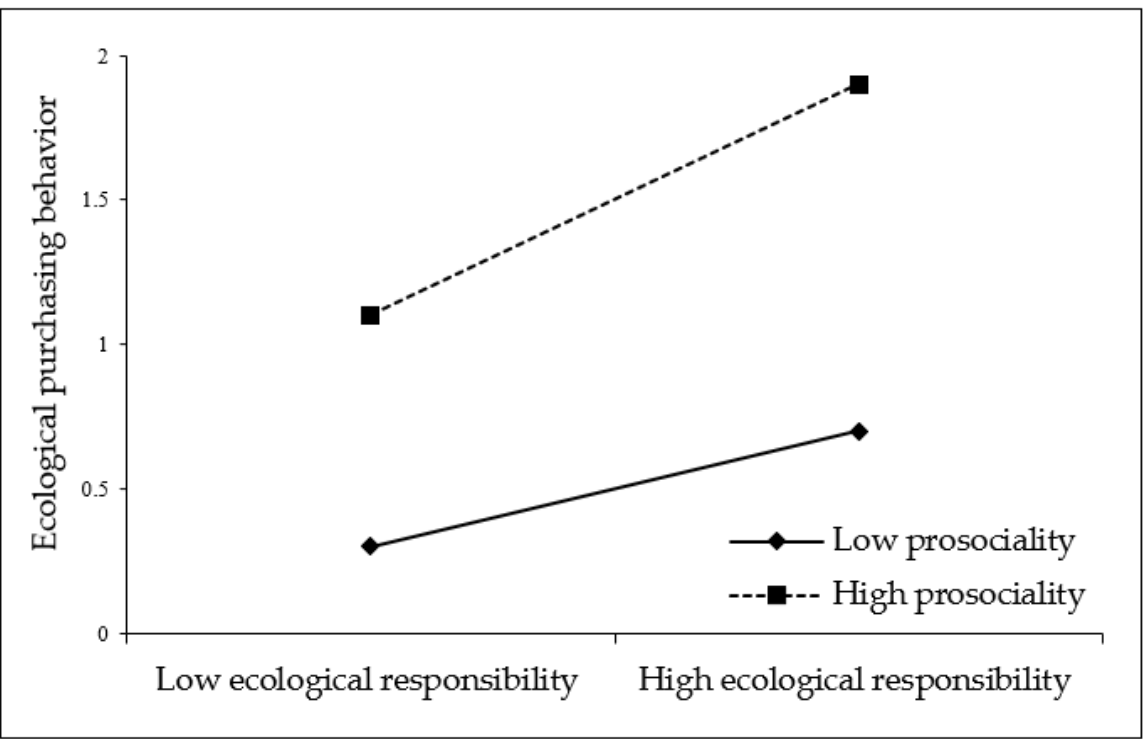

Figure 2. Moderating effect of prosociality on the relationship between ecological responsibility and ecological purchasing behavior.

In addition, this study used ecological purchasing behavior as the dependent variable, ecological attitudes as the independent variable, and added prosociality as the moderating variable for hierarchical regression analysis. As shown in Table 7, the interaction between ecological attitudes and prosociality was significant $(p<0.01)$, which shows that the moderating role of prosociality between ecological attitudes and ecological purchasing behavior was significant. H10 was supported. Similarly, H10 was further examined by a simple slope graph. In Figure 3, compared with a low level of prosociality, the positive impact of ecological attitudes on ecological purchasing behavior was stronger under high prosociality. The possibility of high prosociality influencing ecological purchasing behavior increased faster than that of low prosociality. In other words, the slope was greater. The positive moderating effect of prosociality between ecological attitudes and ecological purchasing behavior was also verified. 


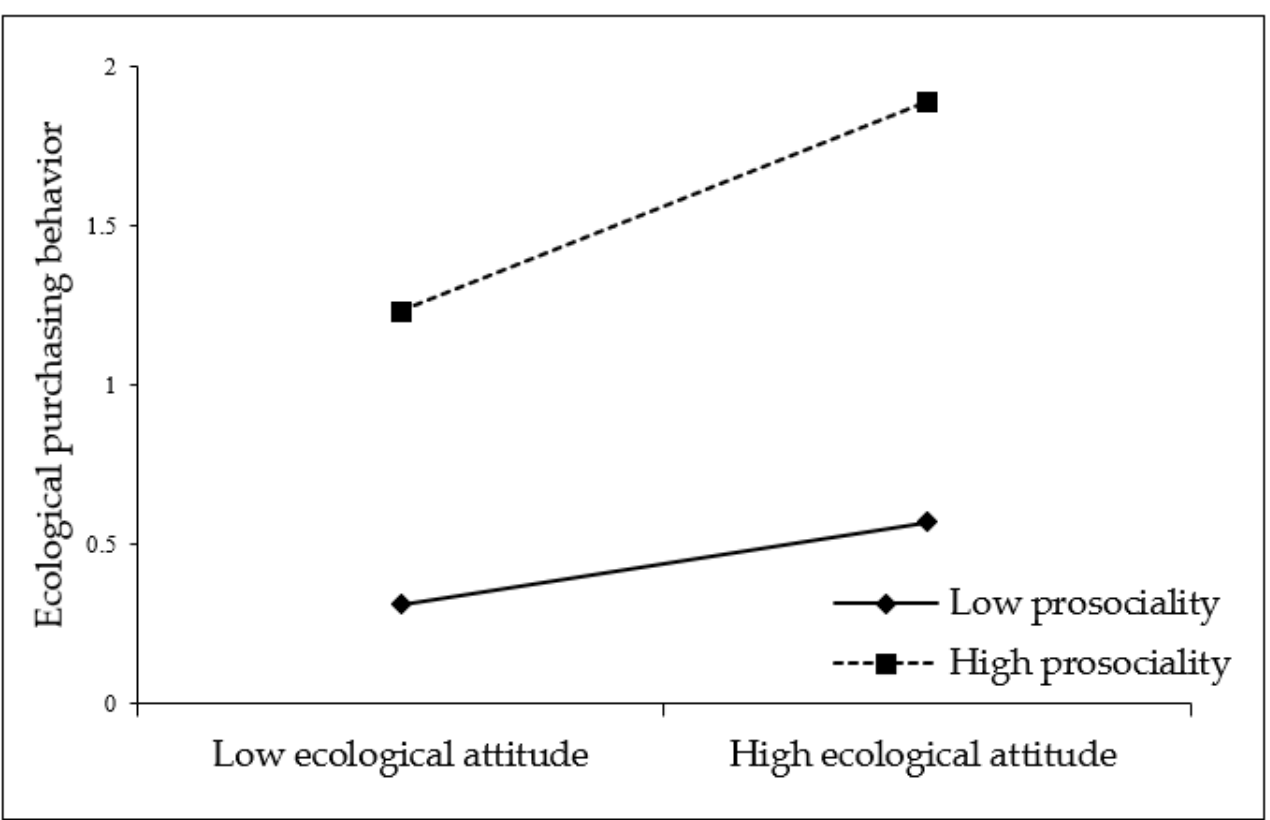

Figure 3. Moderating effect of prosociality on the relationship between ecological attitudes and ecological purchasing behavior.

\section{Discussion}

\subsection{General Discussion}

In this study, we found that there is strong empirical support for the hypothesis that there are positive relationships between environmental concern and both ecological responsibility and ecological attitudes. These relationships in turn positively influenced consumers' ecological consumption behaviors. Prosociality, in addition, moderated the relationships among ecological responsibility, ecological attitudes, and ecological purchasing behavior. We also extended our research in the field of ecological consumption.

First, environmental concern has an indirect influence on ecological responsibility through ecological values and ecological affects. Environmental concern can promote people's ecological values and further stimulate their ecological responsibility in daily shopping. On the other hand, environmental concern evokes consumers' emotional resonance to enhance their ecological responsibility. Therefore, the two impact paths are parallel and without significant differences between them.

Second, environmental concerns can directly affect consumers' ecological attitudes. Ecological values partly contribute to the relationship between environmental concern and ecological attitudes, indicating that consumers with a more positive level of environmental concern will be more likely to have strong ecological values. In addition, values influence consumers' ecological attitudes, which help them to make ecological decisions. Therefore, it can be said that only when people have an awareness of environmental protection can this stimulate their ecological consumption attitudes.

Lastly, when people have a deep sense of responsibility for environmental protection and ecological attitudes, consumers will be more willing to engage in ecological purchasing activities. With different choices available to consumers, strongly ecologically conscious consumers tend to choose goods that are more beneficial to the environment. For example, in the selection of bags, consumers will prefer to use recyclable paper bags. At the same time, prosociality plays an important role in driving consumers' ecological behavior. Consumers with high prosociality are subject to the influence of social context. They can display altruistic and mutual behavior in line with social hope through strong internal self-regulation. This will further enhance ecological purchasing behavior. 


\subsection{Theoretical Implications}

This study explored the mechanism of ecological concern on consumers' eco-purchasing behavior and analyzed the path relationships of the relevant variables. This further enriches the theory related to eco-purchasing behavior. The positive effects of consumer ecological responsibility [28-31,89-91] and ecological attitude [14,19,22-24] on ecological purchasing behavior were verified. Environmental concern, as a psychological cognitive factor, had positive effects on consumers' ecological attitudes. This is consistent with previous studies' findings that environmental concern is a critical predictor of ecological attitudes [41,42]. This study also revealed the mediating role of ecological values between environmental concern and ecological attitudes, which is similar to the findings of Zhang and Luo [39]. However, there was no evidence of a positive relationship between environmental concern and ecological responsibility. On the other hand, ecological affects were proven to help build indirect relationships between environmental concern and ecological responsibility. These results are consistent with previous studies that examined the mechanisms of ecological purchasing behaviors [92,93]. Furthermore, ecological values also played a mediating role between environmental concern and ecological responsibility [94,95].

The empirical findings of this study showed the positive and significant moderating impact of prosociality on ecological purchasing behavior. The results confirmed that if consumers have a high level of prosociality, they tend to have a stronger social identity and are more likely to behave in a beneficial way, according to their moral compass $[76,80]$. Our study further validated the idea that prosociality positively contributes to ecological purchasing behavior, as suggested by Paço et al. [71].

\subsection{Practical Implications}

From the perspective of enhancing the level of ecological consumption, it is essential to raise consumers' environmental concerns. Resource shortages, environmental pollution, and ecological damage have become three major global crises. It is urgent to protect the environment. Many consumers often ignore environmental protection based on their own interests. Therefore, posting various environmental protection slogans, releasing environmental protection videos, or even issuing various environmental protection laws can be beneficial for increasing consumers' environmental concerns. These will also deepen the concept of ecology in consumers' minds and promote a transformation from ordinary consumers to ecological citizens. As people become more ecologically conscious, enterprises should highlight the ecological features of their brands, minimize ecological damage, and use eco-labels. In particular, product packaging design can significantly guide consumers' ecological consumption.

Since prosociality plays an important role in regulating consumers' ecological consumption behavior, more focus should be placed on enhancing consumers' prosociality. For example, on the internet, the release of prosocial information through the experience sharing and posting videos of opinion leaders helps to enhance citizens' prosociality. Social or environmental organizations should lead their members toward more prosocial practices, such as organizing regular charity events, which encourage people to participate in voluntary services. Prosociality also motivates consumers to show empathy and act with altruistic motives, especially in relation to ecological protection. The enhancement of environmental and prosocial education plays a key role in people's subjective perceptions, thus further enabling prosocial behavior. Furthermore, ecological purchasing behavior is a selfless act by consumers to benefit society. Therefore, enhancing consumers' prosociality will contribute to ecological market expansion and further ecological developments, which are important for maintaining environmental sustainability.

\subsection{Limitations and Future Directions}

This study has some limitations. First, we attempted to explore the influencing mechanisms of consumers' ecological purchasing behavior from psychological dimensions. However, the measurement of ecological affects, ecological attitudes, ecological responsi- 
bility, and ecological values is based on consumers' self-assessed responses. Consumers cannot be effectively integrated into the relevant context, and the final measurement results may vary because of consumers' moral assessments. We encourage future researchers to use additional methods (e.g., other-reporting, objective indicators, etc.) to decrease the number of social desirability responses. Second, since the model presented in this study was tested for ecological purchase decisions, it mainly depended on consumers' subjective experiences. Future studies could examine the impact of consumers' ecological concerns and prosociality on their actual purchasing behavior via field research to make the study more objective. Third, there may be concerns about the likelihood of sampling bias due to the use of single-region data. Future research should explore different regions and cultural contexts to further extend the results of this study. Finally, some people are more inclined toward prosociality because of the sources and nature of individual differences. It would be valuable to test whether consumers with higher prosociality tendencies exhibit increased ecological behavior. For example, further research could bring prosociality into specific field research on the environment to examine whether individuals would pay a higher price for an ecological product if they have a higher level of prosociality.

Author Contributions: Conceptualization, L.C. and L.J.; data curation, Q.W.; formal analysis, Q.W.; funding acquisition, L.C.; investigation, Q.W.; methodology, Q.W.; project administration, L.C.; software, Q.W.; supervision, L.J.; validation, L.C. and L.J.; writing—original draft, L.C. and Q.W.; writing-review and editing, L.C. and Q.W. All authors have read and agreed to the published version of the manuscript.

Funding: This study was funded by the National Natural Science Foundation of China (grant number 71472181) and the National Social Science Fund of China (grant number 16BGL090).

Institutional Review Board Statement: This research conducted non-interventional studies. Ethical review and approval were not required for the study on human participants in accordance with the local legislation and institutional requirements.

Informed Consent Statement: Informed consent was obtained from all subjects involved in the study.

Data Availability Statement: Not applicable.

Conflicts of Interest: The authors declare no conflict of interest.

\section{Appendix A}

Table A1. Research variable constructs.

\begin{tabular}{|c|c|c|}
\hline Variable & Item Code & Question \\
\hline \multirow{4}{*}{$\begin{array}{l}\text { Environmental concern } \\
\text { (EC) }\end{array}$} & EC1 & Humans are severely abusing the environment. \\
\hline & EC2 & $\begin{array}{l}\text { If things continue on their present course, we will soon experience a major } \\
\text { ecological catastrophe. }\end{array}$ \\
\hline & EC3 & The balance of nature is very delicate and easily upset. \\
\hline & EC4 & Despite our special abilities, humans are still subject to the laws of nature. \\
\hline \multirow{6}{*}{$\begin{array}{l}\text { Ecological values } \\
\text { (EV) }\end{array}$} & EV1 & It makes me sad to see natural environments destroyed. \\
\hline & EV2 & Nature is valuable for its own sake. \\
\hline & EV3 & One of the most important reasons to conserve is to preserve wild areas. \\
\hline & EV4 & $\begin{array}{c}\text { Nature is important because of what it can contribute to the pleasure and welfare } \\
\text { of humans. }\end{array}$ \\
\hline & EV5 & We need to preserve resources to maintain a high quality of life. \\
\hline & EV6 & $\begin{array}{c}\text { One of the most important reasons to conserve is to ensure a continued high standard } \\
\text { of living. }\end{array}$ \\
\hline
\end{tabular}


Table A1. Cont.

\begin{tabular}{|c|c|c|}
\hline Variable & Item Code & Question \\
\hline \multirow{6}{*}{$\begin{array}{l}\text { Ecological affects } \\
\text { (EAF) }\end{array}$} & EAF1 & It frightens me to think that much of the food I eat is contaminated with pesticides. \\
\hline & EAF2 & $\begin{array}{l}\text { It genuinely infuriates me to think that the government doesn't do more to help } \\
\text { control pollution of the environment. }\end{array}$ \\
\hline & & I become incensed when I think about the harm being done to plant and animal life \\
\hline & EAF3 & by pollution. \\
\hline & EAF4 & I get depressed on smoggy days. \\
\hline & EAF5 & When I think of the ways industries are polluting, I get frustrated and angry. \\
\hline \multirow{3}{*}{$\begin{array}{l}\text { Ecological attitudes } \\
\text { (EAT) }\end{array}$} & EAT1 & I like the idea of purchasing ecologically. \\
\hline & EAT2 & Purchasing ecologically is a good idea. \\
\hline & EAT3 & I have a favorable attitude toward purchasing an ecological version of a product. \\
\hline \multirow{4}{*}{$\begin{array}{l}\text { Ecological responsibility } \\
\text { (ER) }\end{array}$} & ER1 & My actions impact the health of the environment. \\
\hline & ER2 & I have the power to protect the environment. \\
\hline & ER3 & I can learn how to improve the environment. \\
\hline & ER4 & I will work to make my surrounding environment a better place. \\
\hline \multirow{5}{*}{$\begin{array}{l}\text { Prosociality } \\
\text { (PSC) }\end{array}$} & PSC1 & It is important that others are happy. \\
\hline & PSC2 & It is important to help someone who needs it. \\
\hline & PSC3 & I want to help others. \\
\hline & PSC4 & The well-being of others is important. \\
\hline & PSC5 & It is important that all people are happy. \\
\hline \multirow{5}{*}{$\begin{array}{l}\text { Ecological purchasing } \\
\text { behavior } \\
(\mathrm{EPB})\end{array}$} & EPB1 & $\begin{array}{l}\text { I make a special effort to buy paper and plastic products that are made from } \\
\text { recycled materials. }\end{array}$ \\
\hline & EPB2 & I have switched products for ecological reasons. \\
\hline & EPB3 & $\begin{array}{c}\text { When I have a choice between two equal products, I purchase the one less harmful to } \\
\text { other people and the environment. }\end{array}$ \\
\hline & EPB4 & $\begin{array}{l}\text { I make a special effort to buy household chemicals, such as detergents and cleaning } \\
\text { solutions, that are environmentally friendly. }\end{array}$ \\
\hline & EPB5 & $\begin{array}{l}\text { I have avoided buying a product because it had potentially harmful } \\
\text { environmental effects. }\end{array}$ \\
\hline
\end{tabular}

\section{References}

1. Tsai, P.H.; Lin, G.Y.; Zheng, Y.L.; Chen, Y.C.; Chen, P.Z.; Su, Z.C. Exploring the effect of Starbucks' green marketing on consumers' purchase decisions from consumers' perspective. J. Retail. Consum. Serv. 2020, 56, 102162. [CrossRef]

2. Goh, S.K.; Balaji, M.S. Linking green skepticism to green purchase behavior. J. Clean. Prod. 2016, 131, 629-638. [CrossRef]

3. Nguyen, H.V.; Nguyen, N.; Nguyen, B.K.; Lobo, A.; Vu, P.A. Organic food purchases in an emerging market: The influence of consumers' personal factors and green marketing practices of food stores. Int. J. Environ. Res. Public Health 2019, $16,1037$. [CrossRef]

4. Zhang, X.; Dong, F. Why do consumers make green purchase decisions? Insights from a systematic review. Int. J. Environ. Res. Public Health 2020, 17, 6607. [CrossRef] [PubMed]

5. Chan, R.Y.K. Determinants of Chinese consumers' green purchase behavior. Psychol. Mark. 2001, 18, 389-413. [CrossRef]

6. da Silva Tamashiro, H.R.; da Silveira, J.A.G.; Merlo, E.M.; Ghisi, M. The relationship between ecological knowledge, ecological concern, ecological affection, subjective norms and the green purchase behavior in Brazil. Afr. J. Bus. Manag. 2013, 7, 3297-3314. [CrossRef]

7. Yin, J.; Qian, L.; Singhapakdi, A. Sharing sustainability: How values and ethics matter in consumers' adoption of public bicycle-sharing scheme. J. Bus. Ethics 2018, 149, 313-332. [CrossRef]

8. Kaiser, F.G.; Wölfing, S.; Fuhrer, U. Environmental attitude and ecological behavior. J. Environ. Psychol. 1999, 19, 1-19. [CrossRef]

9. Saleki, R.; Quoquab, F.; Mohammad, J. What drives Malaysian consumers' organic food purchase intention? The role of moral norm, self-identity, environmental concern and price consciousness. J. Agribus. Dev. Emerg. Econ. 2019, 9, 584-603. [CrossRef]

10. Ng, M.; Law, M.; Zhang, S. Predicting purchase intention of electric vehicles in Hong Kong. Australas. Mark. J. (AMJ) 2018, 26, 272-280. [CrossRef]

11. Liobikienè, G.; Bernatonienè, J. Why determinants of green purchase cannot be treated equally? The case of green cosmetics: Literature review. J. Clean. Prod. 2017, 162, 109-120. [CrossRef]

12. Xu, X.; Wang, S.; Yu, Y. Consumer's intention to purchase green furniture: Do health consciousness and environmental awareness matter? Sci. Total Environ. 2020, 704, 135275. [CrossRef] [PubMed]

13. Sun, Y.; Wang, S. Understanding consumers' intentions to purchase green products in the social media marketing context. Asia Pac. J. Mark. Logist. 2019, 32, 860-878. [CrossRef] 
14. Steg, L.; Groot, J.D. Explaining prosocial intentions: Testing causal relationships in the norm activation model. Br. J. Soc. Psychol. 2010, 49, 725-743. [CrossRef] [PubMed]

15. Liao, Z. Market orientation and FIRMS' environmental innovation: The moderating role of environmental attitude. Bus. Strategy Environ. 2018, 27, 117-127. [CrossRef]

16. Gifford, R. Environmental psychology matters. Annu. Rev. Psychol. 2014, 65, 541-579. [CrossRef]

17. Schultz, P.W.; Shriver, C.; Tabanico, J.J.; Khazian, A.M. Implicit connections with nature. J. Environ. Psychol. 2004, 24, 31-42. [CrossRef]

18. Ataei, P.; Aliabadi, V.; Norouzi, A.; Sadighi, H. Measuring the employees' environmental attitude of agricultural knowledge-based companies based on sociocultural components: A case study from Iran. Environ. Dev. Sustain. 2019, 21, 2341-2354. [CrossRef]

19. Ajzen, I. The theory of planned behavior: Frequently asked questions. Hum. Behav. Emerg. Technol. 2020, 2, 314-324. [CrossRef]

20. Casaló, L.V.; Escario, J.J. Heterogeneity in the association between environmental attitudes and pro-environmental behavior: A multilevel regression approach. J. Clean. Prod. 2018, 175, 155-163. [CrossRef]

21. Heimlich, J.E.; Ardoin, N.M. Understanding behavior to understand behavior change: A literature review. Environ. Educ. Res. 2008, 14, 215-237. [CrossRef]

22. Adrita, U.W.; Mohiuddin, M.F. Impact of opportunity and ability to translate environmental attitude into ecologically conscious consumer behavior. J. Mark. Theory Pract. 2020, 28, 173-186. [CrossRef]

23. Otto, S.; Evans, G.W.; Moon, M.J.; Kaiser, F.G. The development of children's environmental attitude and behavior. Glob. Environ. Chang. 2019, 58, 101947. [CrossRef]

24. Papaoikonomou, K.; Latinopoulos, D.; Emmanouil, C.; Kungolos, A. A Survey on Factors Influencing Recycling Behavior for Waste of Electrical and Electronic Equipment in the Municipality of Volos, Greece. Environ. Process. 2020, 7, 321-339. [CrossRef]

25. Prakash, G.; Pathak, P. Intention to buy eco-friendly packaged products among young consumers of India: A study on developing nation. J. Clean. Prod. 2017, 141, 385-393. [CrossRef]

26. Pawaskar, U.S.; Raut, R.D.; Gardas, B.B. Assessment of Consumer Behavior towards Environmental Responsibility: A Structural Equations Modeling Approach. Bus. Strategy Environ. 2018, 27, 560-571. [CrossRef]

27. Stone, G.; Barnes, J.H.; Montgomery, C. Ecoscale: A scale for the measurement of environmentally responsible consumers. Psychol. Mark. 1995, 12, 595-612. [CrossRef]

28. Klockner, C.A. A comprehensive model of the psychology of environmental behavior-A meta-analysis. Glob. Environ. Chang.Hum. Policy Dimens. 2013, 23, 1028-1038. [CrossRef]

29. Bhuian, S.N.; Amyx, D.A.; Shamma, H.M. An extension of consumer environmental behavior research among expatriates. Int. J. Commer. Manag. 2014, 24, 63-84. [CrossRef]

30. Follows, S.B.; Jobber, D. Environmentally responsible purchase behaviour: A test of a consumer model. Eur. J. Mark. 2000, 34, 723-746. [CrossRef]

31. Shahrin, R.; Quoquab, F.; Mohammad, J.; Jamil, R. Factors affecting consumers' pro-environmental behaviour in nutricosmetics consumption: The role of perceived environmental responsibility as a mediator. J. Asia Bus. Stud. 2020, 14, 671-689. [CrossRef]

32. Sánchez-Bravo, P.; Chambers, E.; Noguera-Artiaga, L.; López-Lluch, D.; Carbonell-Barrachina, Á.; Sendra, E. Consumers' attitude towards the sustainability of different food categories. Foods 2020, 9, 1608. [CrossRef] [PubMed]

33. Li, Y. Study of the effect of environmental education on environmental awareness and environmental attitude based on environmental protection law of the People's Republic of China. Eurasia J. Math. Sci. Technol. Educ. 2018, 14, 2277-2285. [CrossRef]

34. Dunlap, R.E.; Liere, K.; Mertig, A.G.; Jones, R.E. Measuring endorsement of the new ecological paradigm: A revised NEP Scale. J. Soc. Issues 2000, 56, 425-442. [CrossRef]

35. Straughan, R.D.; Roberts, J.A. Environmental segmentation alternatives: A look at green consumer behavior in the new millennium. J. Consum. Mark. 1999, 16, 558-575. [CrossRef]

36. Freire, O.; Quevedo-Silva, F.; Frederico, E.; Vils, L.; Junior, S.S.B. Effective scale for consumers' environmental concerns: A competing scales study between NEP and ECCB. J. Clean. Prod. 2021, 304, 126801. [CrossRef]

37. Joshi, Y. Investigating the influence of spirituality, environmental concern, and ecological knowledge on consumers' green purchase intention. PURUSHARTHA-A J. Manag. Ethics Spiritual. 2017, 9, 54-61. [CrossRef]

38. Landry, N.; Gifford, R.; Milfont, T.L.; Weeks, A.; Arnocky, S. Learned helplessness moderates the relationship between environmental concern and behavior. J. Environ. Psychol. 2018, 55, 18-22. [CrossRef]

39. Zhang, W.; Luo, B. Do environmental concern and perceived risk contribute to consumers' intention toward buying remanufactured products? An empirical study from China. Clean Technol. Environ. Policy 2021, 23, 463-474. [CrossRef]

40. Lau, J.L.; Hashim, A.H. Mediation analysis of the relationship between environmental concern and intention to adopt green concepts. Smart Sustain. Built Environ. 2019, 9, 539-556. [CrossRef]

41. Chen, C.F.; Eccarius, T.; Su, P.C. The role of environmental concern in forming intentions for switching to electric scooters. Transp. Res. Part. A Policy Pract. 2021, 154, 129-144. [CrossRef]

42. Kirmani, M.D.; Khan, M.N. Environmental concern to attitude towards green products: Evidences from India. Serb. J. Manag. 2016, 11, 159-179. [CrossRef]

43. Antil, J.H. Socially responsible consumers: Profle and implications for public policy. J. Macromark. 1984, 4, 18-39. [CrossRef]

44. Shen, J.Y. Understanding the determinants of consumers' willingness to pay for eco-labeled products: An empirical analysis of the China Environmental Label. J. Serv. Sci. Manag. 2012, 5, 87-94. [CrossRef] 
45. Pekkanen, T.L.; Penttilä, V. The responsibility of an ethnocentric consumer-nationalistic, patriotic or environmentally conscientious? A critical discourse analysis of "buy domestic" campaigns. Int. Mark. Rev. 2021, 38, 300-320. [CrossRef]

46. Janmaimool, P.; Chudech, S. Effect of domestic and global environmental events on environmental concern and environmental responsibility among university students. Sustainability 2020, 12, 1610. [CrossRef]

47. Stern, P.C.; Dietz, T.; Abel, T.; Guagnano, G.A.; Kalof, L. A value-belief-norm theory of support for social movements: The case of environmentalism. Hum. Ecol. Rev. 1999, 6, 81-97.

48. Stern, P.C.; Dietz, T. The value basis of environmental concern. J. Soc. Issues 1994, 50, 65-84. [CrossRef]

49. Grebitus, C.; Steiner, B.; Veeman, M. The roles of human values and generalized trust on stated preferences when food is labeled with environmental footprints: Insights from Germany. Food Policy 2015, 52, 84-91. [CrossRef]

50. Bailey, A.A.; Mishra, A.S.; Tiamiyu, M.F. Application of GREEN scale to understanding US consumer response to green marketing communications. Psychol. Mark. 2018, 35, 863-875. [CrossRef]

51. Slavoljub, J.; Zivkovic, L.; Sladjana, A.; Dragica, G.; Zorica, P.S. To the environmental responsibility among students through developing their environmental values. Procedia-Soc. Behav. Sci. 2015, 171, 317-322. [CrossRef]

52. Liobikienè, G.; Juknys, R. The role of values, environmental risk perception, awareness of consequences, and willingness to assume responsibility for environmentally-friendly behaviour: The Lithuanian case. J. Clean. Prod. 2016, 112, 3413-3422 [CrossRef]

53. Rheu, M. Attitude. Int. Encycl. Media Psychol. 2020, 12, 1-12. [CrossRef]

54. Milfont, T.L.; John, D.; Claire, W. A Cross-Cultural Test of the Value-Attitude-Behavior Hierarchy. J. Appl. Soc. Psychol. 2010, 40, 2791-2813. [CrossRef]

55. Liao, Y.K.; Wu, W.Y.; Pham, T.T. Examining the moderating effects of green marketing and green psychological benefits on customers' green attitude, value and purchase intention. Sustainability 2020, 12, 7461. [CrossRef]

56. Verma, V.K.; Chandra, B.; Kumar, S. Values and ascribed responsibility to predict consumers' attitude and concern towards green hotel visit intention. J. Bus. Res. 2019, 96, 206-216. [CrossRef]

57. Cheung, M.; To, W.M. An extended model of value-attitude-behavior to explain Chinese consumers' green purchase behavior. $J$. Retail. Consum. Serv. 2019, 50, 145-153. [CrossRef]

58. Arnold, M.J.; Reynolds, K.E. Affect and retail shopping behavior: Understanding the role of mood regulation and regulatory focus. J. Retail. 2009, 85, 308-320. [CrossRef]

59. Yeung, C.W.M.; Wyer, R.S., Jr. Affect, appraisal, and consumer judgment. J. Consum. Res. 2004, 31, 412-424. [CrossRef]

60. Larios-Gómez, E. Relation among ecological affect, concern and knowledge and purchase behavior: A study regarding Mexican Consumers. Rev. Bras. Mark. 2019, 18, 73-100. [CrossRef]

61. Chan, H.K. An empirical investigation of green purchase behaviour among the young generation. J. Clean. Prod. 2014, 66, 528-536. [CrossRef]

62. Kao, T.F.; Du, Y.Z. A study on the influence of green advertising design and environmental emotion on advertising effect. J. Clean Prod. 2020, 242, 118294. [CrossRef]

63. Tangney, J.P.; Dearing, R.L.; Gamble, D. Shame and Guilt. J. Forensic Psychiatry Psychol. 2004, 14, 669-674. [CrossRef]

64. Antonetti, P.; Maklan, S. Feelings that make a difference: How guilt and pride convince consumers of the effectiveness of sustainable consumption choices. J. Bus. Ethics 2014, 124, 117-134. [CrossRef]

65. Matthes, J.; Wonneberger, A.; Schmuck, D. Consumers' green involvement and the persuasive effects of emotional versus functional ads. J. Bus. Res. 2014, 67, 1885-1893. [CrossRef]

66. Xiao, C.; Dunlap, R.E. Validating a comprehensive model of environmental concern cross-nationally: A U.S.-Canadian comparison. Soc. Sci. Q. 2007, 88, 471-493. [CrossRef]

67. Gentile, D.A.; Anderson, C.A.; Yukawa, S.; Ihori, N.; Saleem, M.; Ming, L.K.; Sakamoto, A.; Bushman, B.J.; Huesmann, R.; Khoo, A. The effects of prosocial video games on prosocial behaviors: International evidence from correlational, longitudinal, and experimental studies. Personal. Soc. Psychol. Bull. 2009, 35, 752-763. [CrossRef]

68. Kawamura, Y.; Ohtsubo, Y.; Kusumi, T. Effects of cost and benefit of prosocial behavior on reputation. Soc. Psychol. Personal. Sci. 2021, 12, 452-460. [CrossRef]

69. Berman, J.Z.; Silver, I. Prosocial behavior and reputation: When does doing good lead to looking good? Curr. Opin. Psychol. 2022, 43, 102-107. [CrossRef]

70. Gneezy, A.; Imas, A.; Nelson, L.D.; Norton, M. Paying to Be Nice: Consistency and Costly Prosocial Behavior. Manag. Sci. 2011, 58, 179-187. [CrossRef]

71. Paço, A.; Shiel, C.; Alves, H. A new model for testing green consumer behaviour. J. Clean. Prod. 2019, 207, 998-1006. [CrossRef]

72. Dahl, A.; Brownell, C.A. The social origins of human prosociality. Curr. Dir. Psychol. Sci. 2019, 28, 274-279. [CrossRef] [PubMed]

73. Flook, L.; Goldberg, S.B.; Pinger, L.; Davidson, R.J. Promoting prosocial behavior and self-regulatory skills in preschool children through a mindfulness-based Kindness Curriculum. Dev. Psychol. 2015, 51, 44. [CrossRef] [PubMed]

74. Greitemeyer, T. Prosocial modeling: Person role models and the media. Curr. Opin. Psychol. 2022, 44, 135-139. [CrossRef] [PubMed]

75. Misch, A.; Dunham, Y. (Peer) Group influence on children's prosocial and antisocial behavior. J. Exp. Child. Psychol. 2021, 201, 104994. [CrossRef] 
76. Septianto, F. Being moral and doing good to others: Re-examining the role of emotion, judgment, and identity on prosocial behavior. Mark. Intell. Plan. 2017, 35, 180-191. [CrossRef]

77. Mostafa, M.M. A hierarchical analysis of the green consciousness of the Egyptian consumer. Psychol. Mark. 2007, 24, 445-473. [CrossRef]

78. Steele, W.R.; Schreiber, G.B.; Guiltinan, A.; Nass, C.; Glynn, S.A.; Wright, D.J. The role of altruistic behavior, empathetic concern, and social responsibility motivation in blood donation behavior. Transfusion 2008, 48, 43-54. [CrossRef] [PubMed]

79. Aydinli, A.; Bender, M.; Chasiotis, A.; Cemalcilar, Z.; Van de Vijver, F.J. When does self-reported prosocial motivation predict helping? The moderating role of implicit prosocial motivation. Motiv. Emot. 2014, 38, 645-658. [CrossRef]

80. Zabkar, V.; Hosta, M. Willingness to act and environmentally conscious consumer behaviour: Can prosocial status perceptions help overcome the gap? Int. J. Consum. Stud. 2013, 37, 257-264. [CrossRef]

81. Teng, C.C.; Lu, A.; Huang, T.T. Drivers of consumers' behavioral intention toward green hotels. Int. J. Contemp. Hosp. Manag. 2018, 30, 1134-1151. [CrossRef]

82. Maloney, M.P.; Ward, M.P. Ecology: Let's hear from the people: An objective scale for the measurement of ecological attitudes and knowledge. Am. Psychol. 1973, 28, 583-586. [CrossRef]

83. Stern, M.J.; Powell, R.B.; Ardoin, N.M. Evaluating a constructivist and culturally responsive approach to environmental education for diverse audiences. J. Environ. Educ. 2010, 42, 109-122. [CrossRef]

84. Kim, Y.; Choi, S.M. Antecedents of green purchase behavior: An examination of collectivism, environmental concern, and PCE. Adv. Consum. Res. Assoc. Consum. Res. 2005, 32, 592-599.

85. Preacher, K.J.; Hayes, A.F. SPSS and SAS procedures for estimating indirect effects in simple mediation models. Behav. Res. Methods Instrum. Comput. 2004, 36, 717-731. [CrossRef]

86. Aiken, L.S.; West, S.G. Multiple Regression: Testing and Interpreting Interactions; Sage Publications: London, UK, 1991.

87. Dawson, J.F. Moderation in management research: What, why, when, and how. J. Bus. Psychol. 2014, 29, 1-19. [CrossRef]

88. Dawson, J.F.; Richter, A.W. Probing three-way interactions in moderated multiple regression: Development and application of a slope difference test. J. Appl. Psychol. 2006, 91, 917-926. [CrossRef]

89. Yue, B.; Sheng, G.; She, S.; Xu, J. Impact of consumer environmental responsibility on green consumption behavior in China: The role of environmental concern and price sensitivity. Sustainability 2020, 12, 2074. [CrossRef]

90. Al-Haziazi, M.; Muthuraman, S. Consumer environmental responsibility towards green consumption in sultanate of Oman. Kuwait Chapter Arab. J. Bus. Manag. Rev. 2019, 8, 24-37. [CrossRef]

91. Paço, A.; Rodrigues, R.G. Environmental activism and consumers' perceived responsibility. Int. J. Consum. Stud. 2016, 40, 466-474. [CrossRef]

92. Chan, R.Y.K.; Lau, L.B.Y. Antecedents of green purchases: A survey in China. J. Consum. Mark. 2000, 17, 338-357. [CrossRef]

93. Wang, J.; Yam, R.C.M.; Tang, E.P.Y. Ecologically conscious behaviour of urban Chinese consumers: The implications to public policy in China. J. Environ. Plan. Manag. 2013, 56, 982-1001. [CrossRef]

94. Jagers, S.C.; Matti, S. Ecological citizens: Identifying values and beliefs that support individual environmental responsibility among Swedes. Sustainability 2010, 2, 1055-1079. [CrossRef]

95. Hosta, M.; Zabkar, V. Antecedents of environmentally and socially responsible sustainable consumer behavior. J. Bus. Ethics 2020, 171, 273-293. [CrossRef] 